\title{
ARTICLE
}

Cite this: DOI: 10.1039/x0xx00000x

\section{Mixed Alkyl Aryl Phosphonate Esters as Quenched Fluorescent Activity-Based Probes for Serine Proteases}

Received 00th January 2012,

Accepted 00th January 2012

DOI: $10.1039 / \times 0 \times x 00000 x$

www.rsc.org/

\author{
Sevnur Serim ${ }^{a}$ Philipp Baer ${ }^{a}$ and Steven H. L. Verhelst* ${ }^{a, b}$
}

Activity-based probes (ABPs) are powerful tools for the analysis of active enzyme species in whole proteomes, cells or animals. Quenched fluorescent ABPs (qABPs) can be applied for real time imaging, allowing the visualization of dynamic enzyme activation by fluorescent microscopy. Unfortunately, qABPs are only available for a few enzymes. We here describe the design and synthesis of qABPs for serine proteases based on a phosphonate ester scaffold.

\section{Introduction}

During the last decade, chemical proteomics has increasingly been used for the functional characterization of proteins within the context of a whole proteome. In contrast to classical proteomics approaches, the technique of activity-based protein profiling (ABPP) can distinguish between active and inactive enzyme species by using small molecule activity-based probes (ABPs). ${ }^{1-3}$ ABPs rely on a reactive group or 'warhead' that covalently binds to the active site of a specific subset of enzymes, often in a mechanism-based reaction with an active site nucleophile. A reporter tag on the ABP, such as a biotin or a fluorophore, enables subsequent detection of the covalent complex (Fig. 1A). ${ }^{4}$ ABPs have been applied for various purposes including the profiling of enzyme activities in disease models and the screening of enzyme inhibitors in complex proteomes. $^{5-7}$

ABPs have proven especially useful for the study of proteases, ${ }^{8}$ since these enzymes are generally synthesized as inactive zymogens and are tightly regulated by posttranslational processes. Fluorophore-labeled ABPs do not only allow detection of active proteases after gel electrophoresis, but also enable the direct visualization in cells, tissue sections or live animals by microscopy techniques. However, the intrinsic fluorescence of these ABPs requires extensive washing of cells in culture or long clearance times in vivo in order to remove unreacted probe and obtain sufficient contrast, preventing realtime imaging applications. Quenched fluorescent ABPs (qABPs) have been developed to overcome this problem. They rely on a reactive warhead that carries a leaving group to which a fluorescence quencher is attached. This results in an overall dark probe, which only lights up after reaction with the target enzyme (Fig. 1B). The synthesis of qABPs is challenging and thus far, qABPs have only been reported for the clan $\mathrm{CA}$ and clan CD cysteine proteases and for selected phosphatases. ${ }^{9-13}$ In our continuous efforts to develop novel probes for serine proteases, we here describe the design and synthesis of the first qABPs for serine proteases based on mixed alkyl, aryl phosphonates.

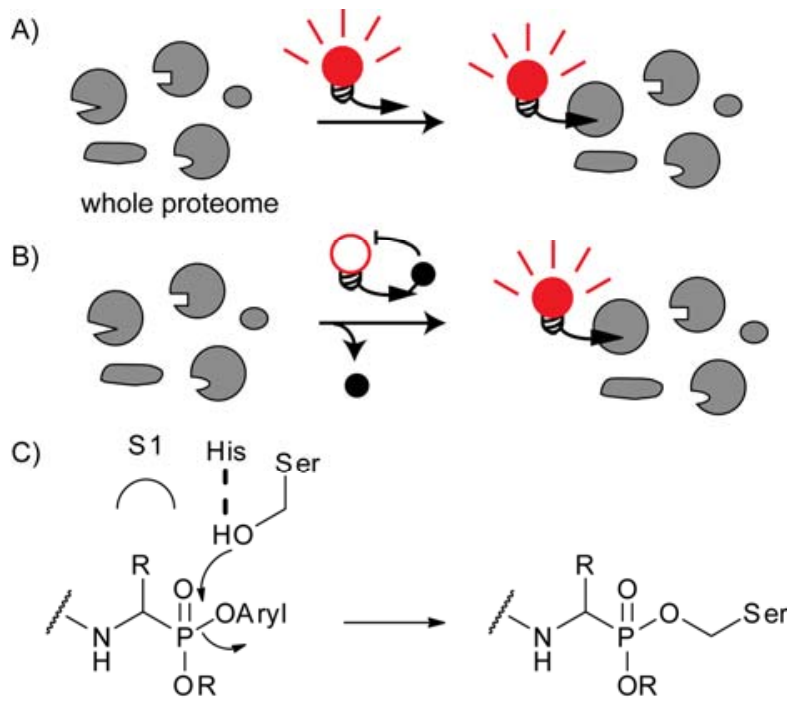

Fig. 1 Activity-based probes and their quenched fluorescent versions. A) The general approach of activity-based protein profiling. The detection tag, here depicted as a light bulb, can range from a fluorophore, biotin or radiotracer to a bioorthogonal detection handle such as an azide or alkyne. B) Fluorescently quenched activity-based probes rely on reactive warhead with a leaving group that contains a fluorescence quencher. C) A diphenyl phosphonate ( $\mathrm{R}$ and Aryl $=\mathrm{Ph}$ ) or alkyl, aryl phosphonate $(\mathrm{R}=$ alkyl) and the covalent attachment to the active site of a serine protease. 

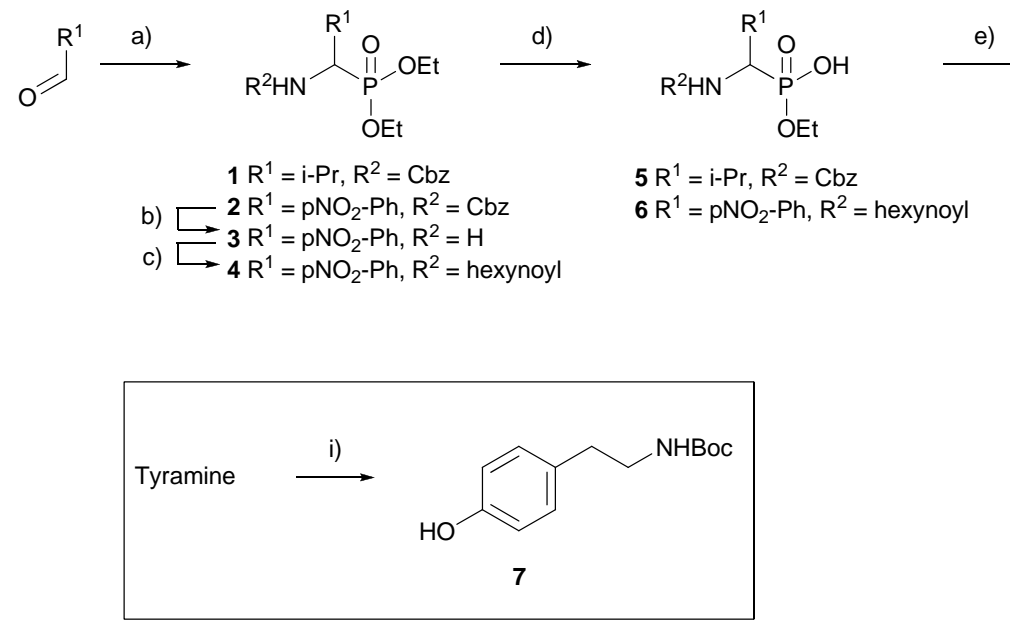

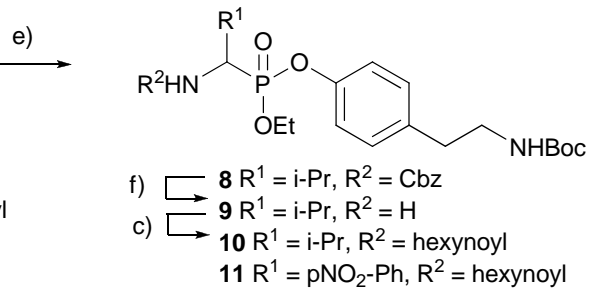

$\downarrow$ g)

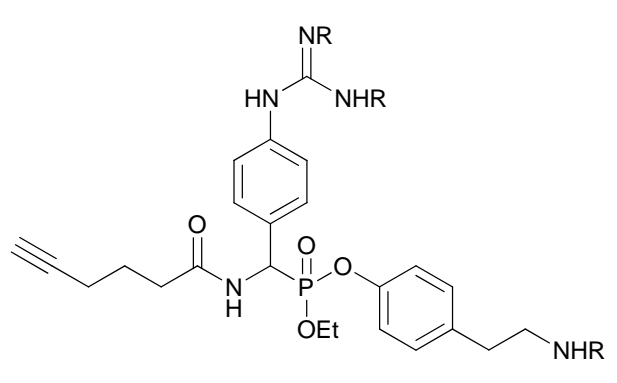

h) $\begin{aligned} 12 \mathrm{R} & =\mathrm{Boc} \\ 13 \mathrm{R} & =\mathrm{H}\end{aligned}$

Scheme 1. Synthesis of the mixed ethyl aryl phosphonate building blocks 10 and 13. a) $\mathrm{Cbz}_{-} \mathrm{NH}_{2}$, diethyl phosphite, $\mathrm{AcCl}, 0{ }^{\circ} \mathrm{C}$, 1h, $88-95 \%$. b) $33 \% \mathrm{HBr} / \mathrm{AcOH}$, 1h. c) hexynoic acid, HATU, DIEA, DMF, overnight, $74 \%$ over 2 steps for compound $4,26 \%$ over 2 steps for compound 10. d) $\mathrm{LiBr}$, 2-butanone, $70{ }^{\circ} \mathrm{C}$, overnight, $65-83 \%$. e) 7, DIC, DMAP, toluene, $70{ }^{\circ} \mathrm{C}$, overnight, $96 \%$ (for compound 8) f) $\mathrm{H}_{2}$, Pd-C, overnight. g) $\mathrm{SnCl}_{2}$, EtOH, $70{ }^{\circ} \mathrm{C}$, 1h, then 1,3-di-Boc-2-(trifluoromethyldulfonyl)guanidine, TEA, $\mathrm{CH}_{2} \mathrm{Cl}_{2}$, overnight, $17 \%$ (for compound 12, 3 steps from 6). h) TFA $/ \mathrm{CH}_{2} \mathrm{Cl}_{2} 1 / 1,1 \mathrm{~h}, 37 \%$. i) $\mathrm{Boc}_{2} \mathrm{O}, \mathrm{Na}_{2} \mathrm{CO}_{3}$, dioxane/ $\mathrm{H}_{2} \mathrm{O}, 1 \mathrm{~h}$, $90 \%$.

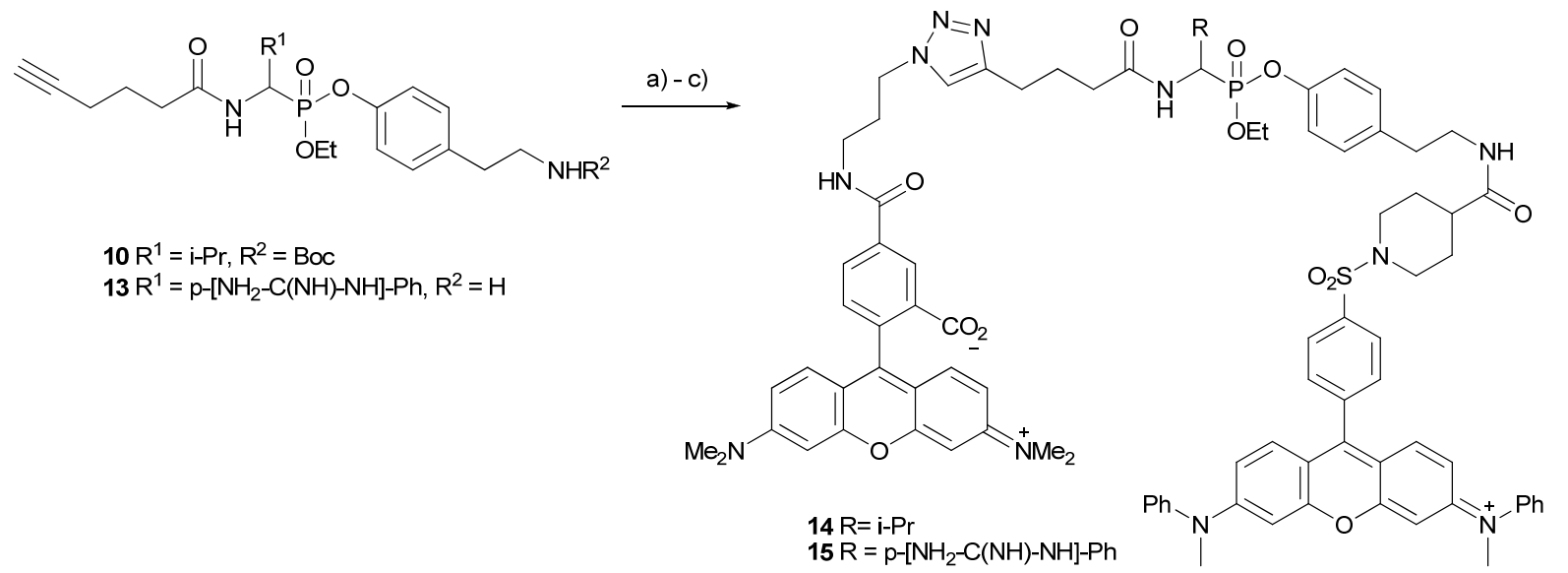

Scheme 2. Synthesis of the qABPs 14 and 15. a) TAMRA-NH- $\left(\mathrm{CH}_{2}\right)_{3}-\mathrm{N}_{3}, \mathrm{Cu}(\mathrm{I})$, THF, overnight. b) $\mathrm{TFA} / \mathrm{CH}_{2} \mathrm{Cl}_{2} 1 / 1,1 \mathrm{~h}$ (for compound 10 only). c) QSy7-OSu, DIEA, dmso, 3h, 3-16\% over 3 steps.

\section{Results and Discussion}

In the past, ABPs for serine protease have utilized several types of electrophilic moieties as warheads, including fluorophosphonates, ${ }^{14},{ }^{15}$ sulfonyl fluorides ${ }^{16}$ and isocoumarins. ${ }^{17-19}$ However, these do not contain leaving groups that can be used for the incorporation of a fluorescence quencher moiety. $\alpha$-Amino diphenyl phosphonates (DPPs), however, contain a phenoxy leaving group, which is expulsed upon reaction with the active site serine of a serine protease (Fig. 1C). Furthermore, the selectivity of DPPs can be adjusted by varying the P1 element as well as by elongation with a longer peptide. Therefore, DPPs have been used as potent and selective serine protease inhibitors and ABPs. ${ }^{20,21}$ In the design for qABPs, it is of crucial importance that the reactive group contains one single leaving group, making diaryl phosphonates unsuitable. To overcome this problem, we synthesized qABPs as mixed alkyl aryl phosphonates, which we made from dialkyl phosphonates by selective removal of one alkyl group, subsequent introduction of the aryl leaving group, and finally introduction of the fluorophore and the quencher.

The starting point of the synthesis consisted of an aldehyde, which will form the P1 element that is recognized by the S1 pocket of the target serine protease. The aldehyde was reacted 
with diethyl phosphite and benzyl carbamate in a Mannich-type condensation, ${ }^{22}$ forming the phosphonate scaffold (Scheme 1). In order to target elastase-like proteases, isobutyraldehyde was used to form the valine-like phosphonate 1. For trypsin-like proteases, p-nitrobenzaldehyde was chosen as a starting material, giving phosphonate 2 with a p-nitrophenyl group. At a later stage, this group can be transformed into a p-guanidinophenyl substituent, a mimic of the arginine side chain. ${ }^{23}$ The Cbz protecting group of 2 was removed with $\mathrm{HBr} / \mathrm{AcOH}$ and the free amine was coupled to a hexynoic acid. The terminal alkyne handle will allow the introduction of a fluorophore by mild click chemistry conditions, which are compatible with the base-labile aryl phosphonate functional group. For the selective hydrolysis of one ethyl group, we initially used saponification with $\mathrm{NaOH}$. However, this reaction resulted in a mixture of products. Gratifyingly, a non-hydrolytic mono-dealkylation by $\mathrm{S}_{\mathrm{N}} 2$ substitution using $\mathrm{LiBr}$ in refluxing 2-butanone ${ }^{24}$ yielded the desired product. A Boc-protected tyramine (7) was introduced by carbodiimide-mediated esterification. For the valine-like molecule, the transformation to a mixed alkyl aryl phosphonate ester was more efficient before introduction of the hexynoic acid group (Scheme 1). We reduced the nitro-group of compound 11 with $\mathrm{SnCl}_{2}$ and reacted the free amine with diBoc-2-(trifluoromethylsulfonyl)guanidine, followed by Bocdeprotection yielding building block 13.

With the two alkyl aryl phosphonates $\mathbf{1 0}$ and $\mathbf{1 3}$ in hand, the stage was set to introduce the fluorophore and quencher groups. First, a tetramethylrhodamine(TMR)-functionalized azidopropylamine was coupled by $\mathrm{Cu}(\mathrm{I})$-catalyzed cycloaddition. Subsequently, a succinimide derivative of QSy7, a powerful fluorescent quencher, was coupled to the amino-function of the tyramine leaving group, yielding qABPs 14 and 15 (Scheme 2).

After the successful synthesis of the two serine protease qABPs, we aimed for a basic evaluation of their labeling and quenching properties. Activity-based labeling by qABPs 14 and 15 was tested on purified serine proteases of different specificities: trypsin and urokinase plasminogen activator, which have preference for basic P1 side chains, chymotrypsin and cathepsin $G$, which prefer large hydrophobic P1 side chains, and pancreatic elastase and neutrophil elastase which show selectivity for small hydrophobic P1 side chains. As expected, the reactivity matched the natural substrate specificity of the target proteases (Fig. 2A): probe $\mathbf{1 5}$ containing the P1 arginine mimic strongly labeled the trypsin-like proteases, whereas the P1 valine probe $\mathbf{1 4}$ showed intense labeling of neutrophil elastase, which prefers a P1 valine residue. Probe 14 displayed weaker labeling of chymotrypsin and pancreatic elastase, which have preference for large hydrophobic and alanine residues, respectively. To show sensitivity of the alkyl, aryl phosphonate qABPs, we labeled a decreasing amount of trypsin with probe $\mathbf{1 5}$ and found that as little as $2 \mathrm{ng}$ of this protease target could be detected (Fig. $\mathrm{S} 1 \dagger$ ). Additionally, we performed labeling of trypsin in the presence of a crude lysate of the human cancer cell line HT-29. The detectable amount of trypsin was $0.025 \%$ of total protein, comparable to other serine protease probes $^{19}$ (Fig. S2†).
For imaging applications, it is of fundamental importance that there is a clear difference between the probe's fluorescence in the unbound/quenched state and the bound/unquenched state. We tested this by incubation of probe $\mathbf{1 5}$ in PBS with or without bovine trypsin as a target protease. Satisfyingly, the signal of the probe was similar to the used buffer, which indicates both the strongly quenched TAMRA fluorescence and the probe stability at physiological $\mathrm{pH}$. As expected, a rapid increase in fluorescence occurred upon reaction with the protease (Fig. 2B).

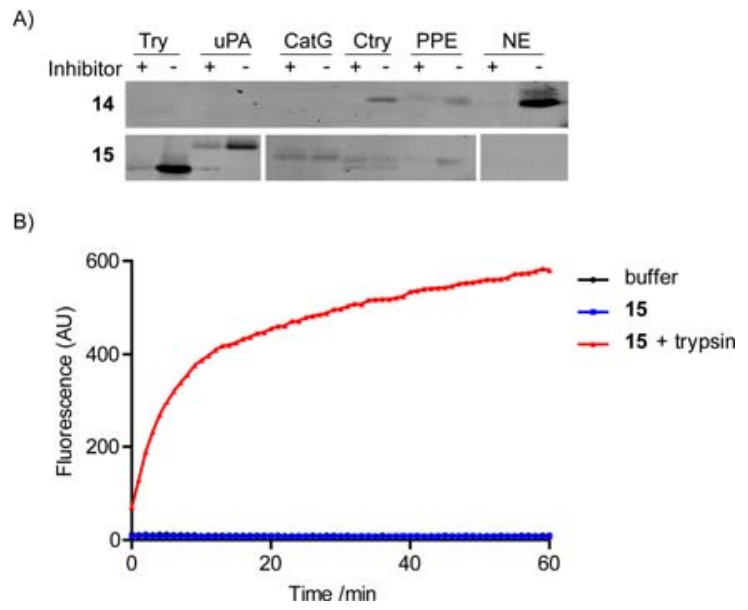

Fig. 2. Evaluation of serine protease qABPs. A) Labeling of serine proteases with qABPs 14 and 15 (Try = bovine trypsin, uPA = human urokinase plasminogen activator, $\mathrm{CatG}=$ human cathepsin $\mathrm{G}, \mathrm{Ctry}=$ bovine chymotrypsin, $\mathrm{PPE}=$ porcine pancreatic elastase, $\mathrm{NE}=$ human neutrophil elastase). Each sample was treated with dmso (-) or an inhibitor $(+)$ before incubation with the qABP. The used inhibitors included DCI for trypsin and elastase, DFP for UPA, PMSF for cathepsin G and DAP22c for chymotrypsin. B) qABP $15(2 \mu \mathrm{M})$ was incubated in PBS with or without bovine trypsin $(0.05 \mathrm{mg} / \mathrm{mL})$ and the fluorescence (ex: $544 \mathrm{~nm}$, em: $590 \mathrm{~nm}$ ) was followed in a 96-well plate reader for $1 \mathrm{~h}$.

\section{Conclusions}

Up to date, qABPs have only been developed for cysteine proteases $^{9-13}$ and for tyrosine phosphatases. ${ }^{13}$ In this paper, we have described the first synthesis of qABPs for serine proteases. They are based on a phosphonate reactive electrophile that, in contrast to previously reported serine protease phosphonate ABPs, are mixed alkyl aryl phosphonates. The biochemical evaluation shows that the phosphonate qABPs covalently label their serine protease targets with expulsion of the fluorescent quencher. The selectivity is steered by the P1 element, and may be further influenced by introduction of extended recognition elements in the $\mathrm{P} 2-\mathrm{P} 4$ positions $^{25}$ As elevated serine protease activities are present in several pathologies such as inflammation and tumorigenesis, we expect that the mixed alkyl aryl phosphonate qABPs as synthesized here will be useful tools for the future study of these processes. Application of these probes in complex proteomes and imaging studies by 
fluorescent microscopy are currently under investigation and will be reported in due course.

\section{Experimental}

\section{Materials and equipment}

Acetic acid, acetyl chloride, human urokinase plasminogen activator and porcine pancreatic elastase were purchased at VWR (Ismaning, Germany), benzyl carbamate, Boc anhydride, chymotrypsin from bovine pancreas type II, copper(I)bromide, diethyl phosphite, diisopropylcarbodiimide (DIC), 4(dimethylamino)pyridine (DMAP), N-diisopropyl-Nethylamine (DIEA), $\mathrm{HBr}(33 \%$ in acetic acid), isobutyraldehyde. lithium bromide, sodium ascorbate, trypsin from bovine pancreas type I, and tyramine were obtained from Sigma-Aldrich (Taufkirchen, Germany), QSy-7 succinimidyl ester was bought from Invitrogen/Life Technologies (Darmstadt, Germany), HATU was purchased at Creosalus (Louisville, KY, USA), $\mathrm{MgSO}_{4}$ was obtained from Carl Roth (Karlsruhe, Germany), and sodium carbonate decahydrate, 2butanone and human neutrophil elastase were received from Applichem (Darmstadt, Germany). TBTA was made as previously described. ${ }^{26}$

Thin layer chromatography (TLC) was performed on ALUGRAM sil G/UV254 TLC plates (Carl Roth, Germany). Solvents used for reactions and purification via column chromatography were purchased from Applichem, Germany. Compounds were separated over silica gel with a grain distribution of $0.04-0.063 \mathrm{~mm}$ and a pore size of $60 \AA$ (Carl Roth, Germany).

LC-MS spectra were recorded by an Agilent 1100 Series LC system coupled to an Agilent 6210 ESI TOF mass spectrometer, with separation on a Zorbax SB C18 $5 \mu \mathrm{m}(0.5 \mathrm{x}$ $150 \mathrm{~mm})$ column and elution by solvents A (5\% MeCN/ $\mathrm{H}_{2} \mathrm{O}+$ $0.1 \%$ formic acid) and $\mathrm{B}\left(95 \% \mathrm{MeCN} / \mathrm{H}_{2} \mathrm{O}+0.1 \%\right.$ formic acid) at a flowrate of $20 \mu \mathrm{l} / \mathrm{min}$. HPLC purifications were carried out on Waters Xbridge BEH130 Prep C18 $5 \mu \mathrm{m}(19 \mathrm{x}$ $150 \mathrm{~mm}$ ) column. ${ }^{1} \mathrm{H}$ NMR spectra were measured on a Bruker $400 \mathrm{MHz}$ DRX or a Bruker $500 \mathrm{MHz}$ Avance III. Chemical shifts $(\delta)$ are given in parts per million (ppm) relative to tetramethylsilane as an internal standard.

\section{Methods}

General procedure for dealkylation with $\mathbf{L i B r}$. The diethyl phosphonate ( 1 eq.) and $\mathrm{LiBr}$ (1.2 eq.) were stirred overnight in butanone $(5 \mathrm{~mL} / \mathrm{mmol})$ under refluxed at $70{ }^{\circ} \mathrm{C}$. The formed precipitate was collected by filtration, washed with diethyl ether and redissolved in $1 \mathrm{M} \mathrm{HCl}$. The water phase was extracted four times with EtOAc and the collected organic layers were washed with brine, dried over $\mathrm{MgSO}_{4}$ and concentrated under reduced pressure. main paragraph text follows directly on here.

General procedure for coupling of 5-hexynoic acid. 5hexynoic acid (2 eq.) was preactivated with HATU (1.9 eq.) and DIEA (4 eq.) in DMF ( $4 \mathrm{~mL}$ ) for $20 \mathrm{~min}$ at $\mathrm{rt}$. To this mixture, the phosphonate with a free $\alpha$-amino group ( 1 eq.) and DIEA (1.6 eq.) in DMF ( $3 \mathrm{~mL}$ ) were added and stirred $\mathrm{o} / \mathrm{n}$ at $\mathrm{rt}$. The solvent was removed, and the oily product was redissolved in EtOAc. The organic phase was washed twice with $1 \mathrm{M} \mathrm{HCl}$, twice with saturated $\mathrm{NaHCO}_{3}$, and brine. The organic layer was dried over $\mathrm{MgSO}_{4}$ and concentrated under reduced pressure.

Diethyl 1-( $N$-benzyloxycarbonyl-amino)-2-methylpropanephosphonate (1). To a mixture of benzyl carbamate (1.51 g, $10 \mathrm{mmol})$, diethyl phosphite $(1.28 \mathrm{~mL} ; 10 \mathrm{mmol})$ and isobutyraldehyde $(1.14 \mathrm{~mL}, 12.5 \mathrm{mmol})$ cooled at $-5{ }^{\circ} \mathrm{C}$ was added dropwise $15 \mathrm{~mL}$ acetyl chloride. The reaction was stirred for $1 \mathrm{~h}$, warmed to room temperature and the mixture was concentrated under reduced pressure. EtOAc was added and the organic phase was washed with water, saturated $\mathrm{NaHCO}_{3}(2 \mathrm{x})$ and brine, dried on $\mathrm{MgSO}_{4}$ and evaporated under reduced pressure. Silica column chromatography (50-100\% EtOAc in petroleum ether) gave the title compound as a colorless oil (3.03 g, 88\% yield). ESI-MS: $\mathrm{m} / \mathrm{z}$ 344.1925, $\mathrm{C}_{16} \mathrm{H}_{27} \mathrm{NO}_{5} \mathrm{P}^{+}$ requires 344.1621. ${ }^{1} \mathrm{H} \mathrm{NMR}\left(400 \mathrm{MHz}, \mathrm{CDCl}_{3}\right) \delta$ 7.38-7.30 (m, $5 \mathrm{H}), 5.19-5.08(\mathrm{~m}, 3 \mathrm{H}), 4.16-3.82(\mathrm{~m}, 5 \mathrm{H}), 2.27-2.17(\mathrm{~m}, 1 \mathrm{H})$, 1.34-1.22 (m, 6H), $1.03(\mathrm{~d}, 3 \mathrm{H}, J=6.8 \mathrm{~Hz}), 1.0(\mathrm{~d}, 3 \mathrm{H}, J=6.9$ $\mathrm{Hz})$.

Diethyl 1-(N-benzyloxycarbonyl-amino)-(4-nitrophenyl)methanephosphonate (2). To a mixture of benzyl carbamate $(0.75 \mathrm{~g}, 5 \mathrm{mmol})$, diethyl phosphite $(0.64 \mathrm{~mL} ; 5$ $\mathrm{mmol})$ and 4-nitrobenzaldehyde $(0.75 \mathrm{~g}, 5 \mathrm{mmol})$ cooled at 0 ${ }^{\circ} \mathrm{C}$ was added dropwise $7.5 \mathrm{~mL}$ acetyl chloride. The reaction was stirred for $1 \mathrm{~h}$, warmed to room temperature and the mixture was concentrated under reduced pressure. EtOAc was added and the organic phase was washed with water, saturated $\mathrm{NaHCO}_{3}(2 \mathrm{x})$ and brine, dried on $\mathrm{MgSO}_{4}$ and evaporated under reduced pressure. Silica column chromatography (50-100\% EtOAc in petroleum ether) gave the title compound as a white solid (2.01 g, 95\% yield). ESI-MS: $\mathrm{m} / \mathrm{z} 423.1368$ (found), $\mathrm{C}_{13} \mathrm{H}_{24} \mathrm{~N}_{2} \mathrm{O}_{7} \mathrm{P}^{+}$requires 423.1316. ${ }^{1} \mathrm{H}$ NMR (500 MHz, DMSO$\left.\mathrm{d}_{6}\right): \delta=8.64(\mathrm{~d}, 1 \mathrm{H}, J=9.2 \mathrm{~Hz}$ ), $8.23(\mathrm{~d}, 2 \mathrm{H}, J=8.6 \mathrm{~Hz}), 7.77$ $(2 \mathrm{H}, \mathrm{d}, J=7.0 \mathrm{~Hz}), 7.41-7.28(\mathrm{~m}, 5 \mathrm{H}), 5.34(\mathrm{dd}, 1 \mathrm{H}, J=23.1$ $\mathrm{Hz}, J=9.9 \mathrm{~Hz}), 5.15-5.00(\mathrm{~m}, 2 \mathrm{H}), 4.03-3.87(\mathrm{~m}, 4 \mathrm{H}), 1.16$ (t, $J=7.1 \mathrm{~Hz}, 3 \mathrm{H}), 1.12(\mathrm{t}, J=7.0 \mathrm{~Hz}, 3 \mathrm{H})$.

Diethyl 1-( $N$-hex-5-ynoyl-amino)-(4-nitrophenyl)methanephosphonate (4). Compound 1 was with $33 \%$ $\mathrm{HBr} / \mathrm{AcOH}$ solution until all the starting material was consumed as indicated by TLC. Next, the solvent was removed under reduced pressure with coevaporation from toluene, giving the product as bright orange solid which was used in the next step without purification. 5-hexynoic acid was coupled as described under the general procedure. Silica column chromatography $(60-80 \%$ EtOAc in petroleum ether) gave the product in $74 \%$ yield as yellowish crystals. ESI-MS: $\mathrm{m} / \mathrm{z}$ 383.1385 (found), $\mathrm{C}_{17} \mathrm{H}_{24} \mathrm{~N}_{2} \mathrm{O}_{6} \mathrm{P}^{+}$requires 383.1366. ${ }^{1} \mathrm{H} \mathrm{NMR}$ $\left(500 \mathrm{MHz}, \mathrm{DMSO}-\mathrm{d}_{6}\right): \delta=9.09(\mathrm{dd}, 1 \mathrm{H}, J=9.6 \mathrm{~Hz}, J=3,0$ $\mathrm{Hz}), 8.24(\mathrm{~d}, 2 \mathrm{H}, J=8.5 \mathrm{~Hz}), 7.74(\mathrm{dd}, 2 \mathrm{H}, J=8.8 \mathrm{~Hz}, J=1.9$ $\mathrm{Hz}), 5.63(\mathrm{dd}, 1 \mathrm{H} . J=22.5 \mathrm{~Hz}, J=9.6 \mathrm{~Hz}), 4.08-3.84(\mathrm{~m}, 4 \mathrm{H})$, 2.78 (t $1 \mathrm{H}, J=2.6 \mathrm{~Hz}), 2.43-2.28(\mathrm{~m}, 2 \mathrm{H}), 2.19-2.13(\mathrm{~m}, 2 \mathrm{H})$, 1.71-1.64 (m, 2H), $1.20(\mathrm{t}, 3 \mathrm{H}, J=7.0 \mathrm{~Hz}), 1.12(\mathrm{t}, 3 \mathrm{H}, J=7.0$ $\mathrm{Hz})$. 
Ethyl 1-( $N$-benzyloxycarbonyl-amino)-2-methylpropanephosphonate (5). Compound $4(686 \mathrm{mg}, 2.0 \mathrm{mmol})$ was dealkylated with $\mathrm{LiBr}$ according to the general procedure affording the title compound as a white solid $(526 \mathrm{mg}, 83 \%$ yield). ESI-MS: $m / z 316.1322$ (found), $\mathrm{C}_{14} \mathrm{H}_{23} \mathrm{NO}_{5} \mathrm{P}^{+}$requires 316.1308. ${ }^{1} \mathrm{H}$ NMR $\left(400 \mathrm{MHz}, \mathrm{CDCl}_{3}\right) \delta 8.72(\mathrm{~s}, 1 \mathrm{H}), 7.36-$ $7.29(\mathrm{~m}, 5 \mathrm{H}), 5.23-5.12(\mathrm{~m}, 3 \mathrm{H}), 4.12-3.97(\mathrm{~m}, 3 \mathrm{H}), 2.24-2.16$ $(\mathrm{m}, 1 \mathrm{H}), 1.26(\mathrm{t}, 3 \mathrm{H}, J=7.0 \mathrm{~Hz}), 1.01(\mathrm{dd}, 3 \mathrm{H}, J=6.9 \mathrm{~Hz}, J=$ $0.9 \mathrm{~Hz}), 0.98(\mathrm{~d}, 3 \mathrm{H}, J=6.9 \mathrm{~Hz})$.

Ethyl 1-( $N$-hex-5-ynylamino)-(4-nitro-phenyl)methanephosphonate (6). 3 (918 $\mathrm{mg}, 2.4 \mathrm{mmol})$ was dealkylated with $\mathrm{LiBr}$ according to the general procedure affording the title compound as a white powder in $65 \%$ yield. ESI-MS: $[\mathrm{M}+\mathrm{H}]^{+} \mathrm{m} / \mathrm{z} 355.1071$ (found), $\mathrm{C}_{15} \mathrm{H}_{20} \mathrm{~N}_{2} \mathrm{O}_{6} \mathrm{P}^{+}$requires 355.1053. ${ }^{1} \mathrm{H}$ NMR $\left(400 \mathrm{MHz}, \mathrm{CDCl}_{3}\right) \delta 8.20(\mathrm{~d}, 2 \mathrm{H}, J=8.6$ $\mathrm{Hz}), 7.60-7.55(\mathrm{~m}, 2 \mathrm{H}), 7.19-7.14(\mathrm{~m}, 1 \mathrm{H}), 5.59(\mathrm{dd}, 1 \mathrm{H}, J=$ $22.3 \mathrm{~Hz}, J=8.8 \mathrm{~Hz}), 4.04-3.96(\mathrm{~m}, 2 \mathrm{H}), 2.46$ (t, $2 \mathrm{H}, J=7.2$ $\mathrm{Hz}), 2.28-2.18(\mathrm{~m}, 2 \mathrm{H}), 1.99(\mathrm{t}, 1 \mathrm{H}, J=2.6 \mathrm{~Hz}), 1.84(\mathrm{t}, 2 \mathrm{H}, J$ $=7.1 \mathrm{~Hz}), 1.24(\mathrm{t}, 3 \mathrm{H}, J=7.1 \mathrm{~Hz})$.

$\mathrm{N}$-tert-butyloxycarbonyl-tyramine (7). To tyramine (274 mg; $2.0 \mathrm{mmol})$, dissolved in $10 \mathrm{~mL}$ dioxane/water $(1 / 1 ; \mathrm{v} / \mathrm{v})$ was added sodium carbonate decahydrate $(572 \mathrm{mg} ; 2 \mathrm{mmol})$. The mixture was cooled in an icebath and Boc anhydride $(480 \mathrm{mg}$; $1.1 \mathrm{eq})$ was added. After $1 \mathrm{~h}$, the reaction was allowed to warm up to room temperature, after which EtOAc was added. The mixture was subsequently washed with $1 \mathrm{M} \mathrm{KHSO}_{4}(2 \mathrm{x})$, water, saturated $\mathrm{NaHCO}_{3}$ and brine. The organic phase was dried on $\mathrm{MgSO}_{4}$, filtered and concentrated under reduced pressure. Silica column chromatography $(20-50 \%$ EtOAc in petroleum ether) yielded the title comound (425 $\mathrm{mg} ; 1.80 \mathrm{mmol} ; 90 \%$ ) as a slightly yellowish oil which solidified upon standing. ESIMS: $m / z \quad 238.1447 \quad[\mathrm{M}+\mathrm{H}]^{+}, 475.2838 \quad[2 \mathrm{M}+\mathrm{H}]^{+}$(found), $\mathrm{C}_{13} \mathrm{H}_{20} \mathrm{NO}_{3}{ }^{+}$requires 238.1438; $\mathrm{C}_{26} \mathrm{H}_{39} \mathrm{~N}_{2} \mathrm{O}_{6}{ }^{+}$requires 475.2803. ${ }^{1} \mathrm{H}$ NMR $\left(400 \mathrm{MHz}, \mathrm{CDCl}_{3}\right) \delta 7.01(\mathrm{~d}, 2 \mathrm{H}, J=8.3$ $\mathrm{Hz}), 6.79(\mathrm{~d}, 2 \mathrm{H}, J=8.5 \mathrm{~Hz}), 6.26(\mathrm{bs}, 1 \mathrm{H}), 4.62(\mathrm{bs}, 1 \mathrm{H})$, 3.37-3.28 (m, 2H), $2.70(\mathrm{t}, 2 \mathrm{H}, J=7.0 \mathrm{~Hz}), 1.44(\mathrm{~s}, 9 \mathrm{H})$.

4-( $N$-Boc-2-aminoethyl)-phenyl, ethyl 1- $(N$ benzyloxycarbonyl-amino)-2-methyl-propane-phosphonate (8). Compound $5(200 \mathrm{mg}, 0.63 \mathrm{mmol})$ and $7(165 \mathrm{mg} ; 0.70$ mmol), coevaporated with toluene, were dissolved in toluene $(3.5 \mathrm{~mL})$ and stirred at $70{ }^{\circ} \mathrm{C}$. Subsequently, DIC $(450 \mu \mathrm{L})$ and DMAP ( $8 \mathrm{mg}$ ) were added, and the solution was stirred overnight. The solvent was evaporated under reduced pressure, the residue dissolved in EtOAc and subsequently washed with 1 $\mathrm{M} \mathrm{KHSO}_{4}$, water, saturated $\mathrm{NaHCO}_{3}$ and brine. Silica column chromatography $(20-70 \%$ EtOAc in petroleum ether) gave the title compound as a white solid (323 mg; $0.60 \mathrm{mmol}, 96 \%$ ). ESI-MS: $\mathrm{m} / \mathrm{z} 535.2596$ (found), $\mathrm{C}_{27} \mathrm{H}_{40} \mathrm{~N}_{2} \mathrm{O}_{7} \mathrm{P}^{+}$requires 535.2568. ${ }^{1} \mathrm{H}$ NMR $\left(400 \mathrm{MHz}, \mathrm{CDCl}_{3}\right) \delta$ 7.40-7.30 (m, 5H), 7.14-7.05 (m, 4H), 5.17-5.06 (m, 3H), 4.54 (bs, $1 \mathrm{H}), 4.25-4.05$ (m, 3H), $3.33(\mathrm{t}, 2 \mathrm{H}, J=6.6 \mathrm{~Hz}), 2.78-2.71(\mathrm{~m}, 2 \mathrm{H}), 2.35-2.26$ (m, 1H), $1.44(\mathrm{~s}, 9 \mathrm{H}), 1.32-1.21(\mathrm{~m}, 3 \mathrm{H}), 1.15-1.03(\mathrm{~m}, 6 \mathrm{H})$.

4-( $N$-Boc-2-aminoethyl)-phenyl, ethyl 1-( $N$-hex-5ynylamino)-2-methyl-propane-phosphonate (10). Compound $8(650 \mathrm{mg}, 1.22 \mathrm{mmol})$ was dissolved in EtOH $(4 \mathrm{~mL}) . \mathrm{Pd} / \mathrm{C}$ (65 mg) and $\mathrm{AcOH}(143 \mu \mathrm{L} ; 2.5$ eq.) were added and the mixture was stirred under $1 \mathrm{~atm}$. hydrogen pressure until all starting material had disappeared. The catalyst was filtered off and the solvent was evaporated, giving compound $\mathbf{9}$, which was used directly in the next step. ESI-MS: $\mathrm{m} / \mathrm{z} 401.2218$ (found), $\mathrm{C}_{19} \mathrm{H}_{34} \mathrm{~N}_{2} \mathrm{O}_{5} \mathrm{P}^{+}$requires 401.2200. 5-hexynoic acid was coupled as described under the general procedure. The crude product was purified by silica column chromatography (50-100\% EtOAc in petroleum ether), giving the title compound as a slightly yellowish oil, which partly solidified upon standing (26\% over 2 steps). ESI-MS: $\mathrm{m} / \mathrm{z} 495.2809$ (found), $\mathrm{C}_{25} \mathrm{H}_{40} \mathrm{~N}_{2} \mathrm{O}_{6} \mathrm{P}^{+}$requires 495.2618. ${ }^{1} \mathrm{H}$ NMR $\left(400 \mathrm{MHz}, \mathrm{CDCl}_{3}\right)$ $\delta 7.16(\mathrm{~d}, 2 \mathrm{H}, J=9.3 \mathrm{~Hz}), 7.11(\mathrm{~d}, 2 \mathrm{H}, J=9.3 \mathrm{~Hz}), 5.94(\mathrm{dd}$, $1 \mathrm{H}, J=19.0 \mathrm{~Hz}, J=8.1 \mathrm{~Hz}), 4.66-4.51(\mathrm{~m}, 2 \mathrm{H}), 4.28-4.16(\mathrm{~m}$, $2 \mathrm{H}), 3.37-3.38(\mathrm{~m}, 2 \mathrm{H}), 2.79-2.72(\mathrm{~m}, 2 \mathrm{H}), 2.47-2.22(\mathrm{~m}, 5 \mathrm{H})$, 2.07-1.98 (m, 1H), 1.93-1.77 (m, 2H), $1.44(\mathrm{~s}, 9 \mathrm{H}), 1.34-1.26$ $(\mathrm{m}, 3 \mathrm{H}), 1.08-1.01(\mathrm{~m}, 6 \mathrm{H})$.

4-( $N$-Boc-2-aminoethyl)-phenyl, ethyl 1-( $N$-hex-5ynylamino)-(4- $N, \quad N$-di-Boc-guanidino-phenyl)methanephosphonate (12). Compound 6 (1.0 eq.) and 7 (1.1 eq.) were dissolved in DMF, and DIC (8 eq.) and DMAP (0.1 eq.) were added. The reaction was set under $\mathrm{N}_{2}$ and heated overnight at $70^{\circ} \mathrm{C}$. The solvent was removed and the oily product was redissolved in EtOAc. The organic layer was then washed $1 \mathrm{x}$ with saturated $\mathrm{NaHCO}_{3}, 1 \mathrm{x}$ with $1 \mathrm{M} \mathrm{HCl}$ and brine, subsequently dried over $\mathrm{MgSO}_{4}$. The solvent was removed under reduced pressure, giving compound $\mathbf{1 1}$ as a white powder, which was used without further purification. ESI-MS: $\mathrm{m} / \mathrm{z} 574.2351$ (found), $\mathrm{C}_{28} \mathrm{H}_{37} \mathrm{~N}_{3} \mathrm{O}_{8} \mathrm{P}^{+}$requires 574.2313. Compound 11 (302 mg, $0.57 \mathrm{mmol}$ ) and $\mathrm{SnCl}_{2}(536 \mathrm{mg}, 5$ eq.) were mixed in EtOH $(2 \mathrm{~mL})$ and refluxed at $70{ }^{\circ} \mathrm{C}$ for $1 \mathrm{~h}$. The solvent was removed and the oily product was redissolved in saturated $\mathrm{NaHCO}_{3}$. The water phase was then extracted 3x with EtOAc. The combined organic phases were washed with brine, dried over $\mathrm{MgSO}_{4}$ and concentrated under reduced pressure. The product was directly used for the next reaction without further purification. ESI-MS: $\mathrm{m} / \mathrm{z} \quad 544.2681$ (found), $\mathrm{C}_{28} \mathrm{H}_{39} \mathrm{~N}_{3} \mathrm{O}_{6} \mathrm{P}^{+}$requires 544.2571. The crude product from the previous reaction $(255 \mathrm{mg}, 0.47 \mathrm{mmol})$ was dissolved in DCM and 1,3-di-Boc-2-(trifluoromethylsulfonyl)guanidine (1.6 eq.) and TEA ( 2 eq.) were added. The mixture was refluxed overnight. The reaction was diluted with DCM and the organic phase was washed with twice with $1 \mathrm{M} \mathrm{KHSO}_{4}$, once with saturated $\mathrm{NaHCO}_{3}$ and brine and subsequently dried over $\mathrm{MgSO}_{4}$. The solvent was removed under reduced pressure and the crude product was purified by silica column chromatography (isocratic elution with EtOAc/petroleum ether $1 / 1)$. The target compound was isolated as white crystals in $17 \%$ yield over 3 steps. ESI-MS: $\mathrm{m} / \mathrm{z} 786.4120$ (found), $\mathrm{C}_{39} \mathrm{H}_{57} \mathrm{~N}_{5} \mathrm{O}_{10} \mathrm{P}^{+}$requires 786.3838. ${ }^{1} \mathrm{H}$ NMR $(500 \mathrm{MHz}$, DMSO$\left.\mathrm{d}_{6}\right): \delta 11.4(\mathrm{~s}, 1 \mathrm{H}), 10.02(\mathrm{~s}, 1 \mathrm{H}), 9.03(\mathrm{dd}, 1 \mathrm{H} J=9.8 \mathrm{~Hz}, J=$ $1.7 \mathrm{~Hz},), 7.58-7.52(\mathrm{~m}, 2 \mathrm{H}), 7.48(\mathrm{~d}, 2 \mathrm{H}, J=7.1 \mathrm{~Hz}), 7.17(\mathrm{~d}$, $2 \mathrm{H}, J=8.5 \mathrm{~Hz}), 7.02(\mathrm{~d}, 2 \mathrm{H}, J=8.2 \mathrm{~Hz}), 6.85(\mathrm{t}, 1 \mathrm{H}, J=5.4$ $\mathrm{Hz}), 5.65(\mathrm{dd}, 1 \mathrm{H}, J=21.5 \mathrm{~Hz}, J=9.8 \mathrm{~Hz}), 4.02(\mathrm{q}, 2 \mathrm{H}, J=7.2$ $\mathrm{Hz}), 3.14-3.08(\mathrm{~m}, 2 \mathrm{H}), 2.77(\mathrm{t}, J=2.6 \mathrm{~Hz}, 1 \mathrm{H}), 2.66(\mathrm{t}, 2 \mathrm{H}, J$ $=7.5 \mathrm{~Hz}), 2.32-2.26(\mathrm{~m}, 2 \mathrm{H}), 2.16-211(\mathrm{~m}, 2 \mathrm{H}), 1.68-1.61$ 
(quint, 2H, $J=7.3 \mathrm{~Hz}), 1.51(\mathrm{~s}, 9 \mathrm{H}), 1.41(\mathrm{~s}, 9 \mathrm{H}), 1.37(\mathrm{~s}, 9 \mathrm{H})$, $1.18(\mathrm{~d}, J=7.1 \mathrm{~Hz}, 3 \mathrm{H})$.

4-(N-QSy7-2-aminoethyl)-phenyl, ethyl 1-(3-(3-( $N$ tetramethylrhodaminylamino)propyltriazolyl)butanoylamin o)-2-methyl-propane-phosphonate

(14).

Tetramethylrhodaminylaminopropylazide (TAMRA-propyl- $\mathrm{N}_{3}$ ) (1.1 eq.) and compound $10(2.0 \mu \mathrm{mol}, 1.0$ eq.) were mixed with $\mathrm{CuBr}(1 \mathrm{mM})$, TBTA $(2 \mathrm{mM})$ and sodium ascorbate (10 $\mathrm{mM})$ in $t-\mathrm{BuOH} /$ water $1 / 1(50 \mu \mathrm{L})$. The reaction heated overnight at $40{ }^{\circ} \mathrm{C}$ under nitrogen, when ESI-MS showed the formation of the triazole adduct. ESI-MS: $\mathrm{m} / \mathrm{z}$ 504.2381 (found), $\mathrm{C}_{53} \mathrm{H}_{69} \mathrm{~N}_{8} \mathrm{O}_{10} \mathrm{P}^{2+}$ requires 504.2432. The solvent was removed under reduced pressure and the crude compound was treated with TFA/DCM $(1 / 1)+2.5 \%$ water $(50 \mu \mathrm{L})$ for $1 \mathrm{~h}$. The solvent was removed in vacuo and the product was detected by ESI-MS: $m / z \quad 454.2139$ (found), $\mathrm{C}_{48} \mathrm{H}_{61} \mathrm{~N}_{8} \mathrm{O}_{8} \mathrm{P}^{2+}$ requires 454.2169. The resulting free amine was coupled to QSy7 succinimidyl ester (1.1 eq.) in dmso $(50 \mu \mathrm{L})$ with DIEA $(1.8$ eq.). After $3 \mathrm{~h}$, the reaction mixture was purified by RP-HPLC. Product containing fractions were pooled and lyophilized, giving probe 14 as a purple powder $(16 \%$ yield over three steps). ESI-MS: $\mathrm{m} / \mathrm{z} 1546.6544$ (found), $\mathrm{C}_{87} \mathrm{H}_{93} \mathrm{~N}_{11} \mathrm{O}_{12} \mathrm{PS}^{+}$ requires 1546.6458 .

4-( $N$ - QSy7-2-aminoethyl)-phenyl, ethyl 1-(3-(3-( $N$ tetramethylrhodaminylamino)propyltriazolyl)butanoylamin o)-(4-guanidino-phenyl)-methanephosphonate

(15).

Compound 12 was Boc-deprotected in TFA/DCM (1/1) for 30 min. The solvent was removed and the oily product was purified by HPLC, giving a white power in 37\% yield. ESI-MS: $\mathrm{m} / \mathrm{z} 486.2244$ (found), $\mathrm{C}_{24} \mathrm{H}_{33} \mathrm{~N}_{5} \mathrm{O}_{4} \mathrm{P}^{+}$requires 486.2265. The product was coupled by click chemistry to TAMRA-propyl- $\mathrm{N}_{3}$ as described above, purified by HPLC and isolated as a pink powder after lyophilization (16\%). The QSy-7 succinimidyl ester was coupled as described above and the final product $\mathbf{1 5}$ was isolated after HPLC purification in $18 \%$ yield as a purple powder. ESI-MS: m/z 1638.6591 (found), $\mathrm{C}_{91} \mathrm{H}_{94} \mathrm{~N}_{14} \mathrm{O}_{12} \mathrm{PS}^{+}$ requires 1637.6628 .

Labeling of proteases. Each protease (375 ng) in PBS was labeled in a final volume of $50 \mu \mathrm{L}$. It was first treated for 30 min with $1 \%$ dmso or an inhibitor ( $1 \mathrm{mM}$ DCI for trypsin and elastase), $100 \mu \mathrm{M}$ DFP for uPA, $1 \mathrm{mM}$ PMSF for cathepsin G and $100 \mu \mathrm{M}$ DAP22c for chymotrypsin). Subsequently, each sample was incubated for $30 \mathrm{~min}$ with probe $\mathbf{1 4}(5 \mu \mathrm{M})$ or $\mathbf{1 5}(2$ $\mu \mathrm{M})$, which were diluted from a $100 \mathrm{x}$ stock in dmso. The proteins were resolved on a $15 \%$ SDS-PAGE gel $(30 \%$ of the sample volume was loaded) and scanned with a typhoon TRIO+ fluorescent scanner.

Unquenching experiment. The experiment was conducted in a black 96-well plate with each sample volume equaling $100 \mu \mathrm{L}$. As a blank control $98 \mu \mathrm{L}$ PBS and $2 \mu \mathrm{L}$ dmso were used. Compound $15(2 \mu \mathrm{L}$ from a $100 \mu \mathrm{M}$ dmso stock) and $98 \mu \mathrm{L}$ PBS constituted the no protease control, whereas compound 15 ( $2 \mu \mathrm{L}$ from a $100 \mu \mathrm{M}$ dmso stock), $93 \mu \mathrm{L}$ PBS and $5 \mu \mathrm{L}$ bovine trypsin (1 $\mathrm{mg} / \mathrm{mL}$ in PBS) were mixed to observe the unquenching. The reactions were followed for $120 \mathrm{~min}$ in a fluorimeter (FLUOstar OPTIMA, BMG labtech) with an excitation filter of $544 \mathrm{~nm}$ and emission filter of $590 \mathrm{~nm}$ ).

\section{Acknowledgements}

We thank Dr. Oliver Frank for measuring NMR samples, Prof. Dr. Dieter Langosch for general support. We acknowledge funding by the Emmy Noether Program of the German Research Foundation and the TUM Junior fellow fund.

\section{Notes and references}

a Lehrstuhl für Chemie der Biopolymere, Technische Universität München, Weihenstephaner Berg 3, 85354 Freising, Germany.

${ }^{b}$ Leibniz Institute for Analytical Sciences, ISAS, e.V., Otto-Hahn-Str. 6b, 44227 Dortmund, Germany.

Electronic Supplementary Information (ESI) available: Supporting figures, and copies of chromatograms and spectra. See DOI: $10.1039 / \mathrm{b} 000000 \mathrm{x} /$

1. B. F. Cravatt, A. T. Wright and J. W. Kozarich, Annu. Rev. Biochem., 2008, 77, 383-414.

2. W. P. Heal, T. H. T. Dang and E. W. Tate, Chem. Soc. Rev., 2011, 40, 246-257.

3. S. H. L. Verhelst and M. Bogyo, QSAR Comb. Sci., 2005, 24, 261269.

4. A. M. Sadaghiani, S. H. L. Verhelst and M. Bogyo, Curr. Opin. Chem. Biol., 2007, 11, 20-28.

5. W. P. Heal, S. R. Wickramasinghe and E. W. Tate, Curr. Drug. Discov. Technol., 2008, 5, 200-212.

6. M. J. Niphakis and B. F. Cravatt, Annu. Rev. Biochem., 2014, 83, 341-377.

7. A. B. Berger, P. M. Vitorino and M. Bogyo, Am. J. Pharmacogenomics, 2004, 4, 371-381.

8. S. Serim, U. Haedke and S. H. L. Verhelst, ChemMedChem, 2012, 7, 1146-1159.

9. G. Blum, S. R. Mullins, K. Keren, M. Fonovic, C. Jedeszko, M. J. Rice, B. F. Sloane and M. Bogyo, Nat. Chem. Biol., 2005, 1, 203209.

10. G. Blum, G. von Degenfeld, M. J. Merchant, H. M. Blau and M. Bogyo, Nat. Chem. Biol., 2007, 3, 668-677.

11. L. E. Edgington, A. B. Berger, G. Blum, V. E. Albrow, M. G. Paulick, N. Lineberry and M. Bogyo, Nat. Medicine, 2009, 15, $967-$ U177.

12. M. Verdoes, K. Oresic Bender, E. Segal, W. A. van der Linden, S. Syed, N. P. Withana, L. E. Sanman and M. Bogyo, J. Am. Chem. Soc., 2013, 135, 14726-14730.

13. M. Hu, L. Li, H. Wu, Y. Su, P.-Y. Yang, M. Uttamchandani, Q.-H. Xu and S. Q. Yao, J. Am. Chem. Soc., 2011, 133, 12009-12020.

14. Y. S. Liu, M. P. Patricelli and B. F. Cravatt, Proc. Natl. Acad. Sci. USA, 1999, 96, 14694-14699.

15. D. Kidd, Y. S. Liu and B. F. Cravatt, Biochemistry, 2001, 40, $4005-$ 4015.

16. D. A. Shannon, C. Gu, C. J. McLaughlin, M. Kaiser, R. A. van der Hoorn and E. Weerapana, ChemBiochem, 2012, 13, 2327-2330.

17. C. M. Kam, A. S. Abuelyaman, Z. Z. Li, D. Hudig and J. C. Powers, Bioconjugate Chem., 1993, 4, 560-567. 
18. S. Arastu-Kapur, E. L. Ponder, U. P. Fonovic, S. Yeoh, F. Yuan, M. Fonovic, M. Grainger, C. I. Phillips, J. C. Powers and M. Bogyo, Nat. Chem. Biol., 2008, 4, 203-213.

19. U. Haedke, M. Gotz, P. Baer and S. H. L. Verhelst, Bioorg. Med. Chem., 2012, 20, 633-640.

20. M. Sienczyk and J. Oleksyszyn, Curr. Med. Chem., 2009, 16, 16731687.

21. R. Grzywa and M. Sienczyk, Curr. Pharm. Des., 2013, 19, 11541178.

22. C. Yuan, G. Wang and S. Chen, Synthesis, 1990, 522-524.

23. M. Sienczyk and J. Oleksyszyn, Bioorg. Med. Chem. Lett., 2006, 16, 2886-2890.

24. H. Krawczyk, Syn. Comm., 1997, 27, 3151-3161.

25. U. Haedke, E. V. Kuttler, O. Vosyka, Y. Yang and S. H. L. Verhelst, Curr. Opin. Chem. Biol., 2013, 17, 102-109.

26. T. R. Chan, R. Hilgraf, K. B. Sharpless, V. V. Fokin, Org. Lett., 2004, 6, 2853-2855. 